\title{
Třeboňský pohled na zpřístupňování archivů
}

\section{Aleš František Plávek (ed.), Digitalizace v pamětových institucích / Digitization in memory institutions, Archivum Trebonense 14, 2017 Třeboň 2017, 734 s., ISBN 978-80-906860-1-4}

V září roku 2017 se ve zrekonstruovaných prostorách Schwarzenberského sálu třeboňského zámku uskutečnila tř́́denní odborná konference Digitalizace v pamětových institucích. Podnětem pro její uskutečnění se stalo desáté výročí zahájení digitalizace ve Státním oblastním archivu v Třeboni. Tento digitalizační projekt se od svého počátku v únoru roku 2007 zaměřil na dálkové zpř́stupnění nejvyužívanějších archivních materiálů badatelům z řad šroké veřejnosti. S ohledem na strukturu fondů uložených v jihočeských archivech nepřekvapí, že se prvořadě jednalo o prameny sloužící především pro genealogický výzkum.

Dlouhodobý projekt, jehož výsledky jsou dostupné na webových stránkách, ${ }^{1}$ ukázal po uplynulé dekádě potřebnost digitalizace nejen materiálů SOA Třeboň, ale i dalších okresních archivů v jižních Čechách. Výsledky digitalizace byly prezentovány vždy po skončení přednáškových bloků po všechny tři dny konference $\mathrm{v}$ prakticky zaměřeném workshopu DigiArchiv pro všechny, který zahrnoval i ukázky práce s webovou aplikací. Představení se ujal Martin Hankovec, jenž je zároveň původním tvưrcem digitálního archivu a jeho hlavním dosavadním vývojářem.

Při moderování samotných konferenčních bloků se během konference vystřídali organizátoři z řad pracovníků SOA Třeboň. Na prvním místě si zmínku zaslouží účast zahraničních hostů. Hned první den tak např́íklad regionální manažerka genealogické společnosti FamilySearch International Inna Anatolija Koňušin účastníky konference bliže seznámila s výsledky spolupráce s archivy v České republice. V druhém konferenčním dni pak zahraniční inspiraci na poli digitalizace v Rakousku poskytli Gerhard Marckhgott z Oberösterreichisches Landesarchiv v Linci a Werner Berthold z Niederösterreichisches Landesarchiv v Sankt Pöltenu.

Z četných př́spěvků týkajících se českých institucí lze namátkou zmínit vystoupení Marie Tůmové a Lucie Swierczekové z Národního muzea o postupu při digitalizaci sbírky skleněných diapozitivů $\mathrm{z}$ fotoarchivu tělesné výchovy a sportu. Zajímavé srovnání $\mathrm{k}$ tomuto př́istupu následně dodala Zuzana Meisnerová Wismer při líčení vzniku digitálního archivu ze skleněných negativů Ateliéru Langhans v Praze.

Na konferenci prezentovali svůj př́spěvek také pracovníci Ústavu dějin a archivu Univerzity Karlovy Petr Cajthaml a Lenka Vašková, kteří představili pokroky v digitalizačním projektu Studenti pražských univerzit 1882-1945. Cílem projektu je digitalizovat a zpř́istupnit na webu matriky, rigorózní protokoly a další materiály posluchačů Univerzity Karlovy a Německé univerzity v Praze.

Složení přednášejících př́ijemně překvapilo svým rozsahem: od pracovníků veřejné správy až po zástupce soukromého sektoru z České republiky i zahraničí.

Nemalou část účastníkủ konference pobavil také unikátní způsob, kterým byli přednášející upozorňováni na ubíhající čas určený pro přednesení jejich příspěvku, a to za pomoci velmi typické a výrazné zvukové signalizace, která striktně vymezovala poslední minutu

$1 \quad$ Viz $<$ https://digi.ceskearchivy.cz> (ověřeno 29. 1. 2018). 
vyhrazenou pro přednesení př́spěvku. Nutno konstatovat, že se jednalo o poměrně efektivní způsob, který lze jiným organizátorům konferencí jedině doporučit. Přičteme-li k pozitivům konference genia loci třeboňského zámku, dostatek kvalitní kávy a možnost ochutnat místní rybí speciality, lze si jen přát, aby se podobné konference konaly častěji.

Trochu netypicky již před samotnou konferencí vznikla na základě autorských textů po všech stránkách velmi výpravná publikace, kterou v poměrně krátké době připravil k vydání kolektiv vedený editorem Alešem Františkem Plávkem. Recenzovaný sborník odborných prací, který je 14. číslem řady Archivum Trebonense, vydávané od roku 1971, na první pohled upoutá nejen mnohasetstránkovým rozsahem zasazeným do kvalitní pevné vazby, ale také svým precizním grafickým zpracováním. Nešetřilo se ani s množstvím obrazových př́loh, které jsou pro pochopení některých textů naprosto klíčové.

Sborník je rozčleněn na dva hlavní oddíly. První, nazvaný Trebonensia, zahrnuje př́ispěvky věnované digitalizaci v jižních Čechách. Texty zaměřené na další pestrou problematiku pak lze nalézt v oddílu Varia. Soubor př́spěvků, které zazněly na konferenci, je dále doplněn také tematickými rozhovory či úctyhodným bibliografickým přehledem pracovníků jihočeských archivů pro období let 2011-2015. Sborník byl vydán také v elektronické podobě, na webu jsou proto na rozdíl od tišstěné verze dostupné i souhrnné rejstř́iky. ${ }^{2}$

Díky svému záběru poskytuje publikace velice komplexní a podrobný přehled současných digitalizačních projektů realizovaných na různých odborných i vědeckých pracovištích nejen v České republice. Sborník také přehledným způsobem vystihuje posun, který se na poli archivářské práce odehrál přinejmenším za poslední desetiletí a sdílením postupů přináší vhodnou inspiraci.

Konečně jak uvádí sám editor: „Je nám potěšením představit veřejnosti digitalizaci jako věc prospěšnou a vítanou, at už ve směru ke správcuim, zpracovatelüm a uživatelưm či nakonec k samotnému historickému dédictví nedozírné hodnoty, které tím chráníme a popularizujeme. ${ }^{\text {"3 }}$ Oba počiny, tedy konference i sborník, zcela jistě tyto ambice naplňují vrchovatou měrou.

Jan Jindra

doi: $10.14712 / 23365730.2018 .42$

2 Elektronická verze sborníku je dostupná na webu $<\mathrm{https}$ :/digi.ceskearchivy.cz $>\mathrm{v}$ sekci Digitalizované materiály - Periodika - Archivum Trebonense.

3 Aleš František Plávek (ed.), Digitalizace v pamětových institucích, Archivum Trebonense 14, 2017, s. 23. 